\title{
Clinical and Diagnostic Studies of Contagious Ecthyma (ORF) In Sheep
}

\author{
Kamal M Al Saad ${ }^{1}$, Haziem T.Thweni ${ }^{2}$, Diheya A.Abdali ${ }^{1}$, Asma Salim Tarik $^{1}$ \\ ${ }^{I}$ (Department of Internal and preventive medicine, College of Veterinary Medicine, University of Basrah, Iraq), \\ ${ }^{2}$ (Department of Microbiology, College of Veterinary Medicine, University of Basrah, Iraq)
}

Corresponding Author: Kamal M Al Saad ${ }^{l}$

\begin{abstract}
Contagious ecthyma in sheep of Basrah, Iraq were detected clinically and diagnosed. The study was carried out on one hundred thirty two sheep, aged 3-8 months and of both sexes reared in Basrah Governorate, Basrah Iraq. One hundred and twenty two animals show the pathognomic clinical manifestations of contagious ecthyma and, Ten clinically normal sheep were considered as controls. Disease animals show signs of anorexia, depression and dullness, Moreover, contagious ecthyma lesions are severe and restricted to the skin in the form of excretive, inclusive, diffusive painful papular and or pustuler lesions appear at mouth commeasure ,upper and lower part of lips and on the muzzle, Moreover, Some infective lesions were appear also on nose, Furthermore, lesion of upper eye lid were indicated in one animal, On the other hand some animals show more advanced lesions in the form of thicker, brownish, rapidly accretive scabs with granulation, which when removed, leave an area of raw bleeding. Orf lesions had offensive odor and in severe infection fissures were observed on the lower lip. Diagnosis of contagious ecthyma virus confirmed by PCR test, thereby samples were found positive show the predicted PCR amplicon size of $408 \mathrm{bp}$, Moreover, a significant increase was encountered in body temperature, respiratory and heart rate of diseased sheep than in controls, In addition results of hematological examinations indicated leukocytosis and lymphocytosis whereas the sedimentation rate of erythrocytes were significantly increased, Moreover, a significant increaser in haptoglobin and Fibrinigen time were indicated in diseased sheep compared with controls.
\end{abstract}

Keywords: Contagious ecthyma, Clinical study, PCR, sheep.

\section{Introduction}

Contagious ecthyma, is a skin viral disease, highly contagious and zoonotic, that affects sheep, goats and some other domesticated and wild ruminants, manifested by appearance of skin lesions which are painful and often occur on the mouth and muzzle, where they can cause anorexia or starvation (Nandi et al, 2011., Scott , 2015 ., Constable et al ,2017 ). The infection in sheep and goats is generally known as orf, contagious ecthyma, infectious labial dermatitis, scabby mouth, contagious pustular dermatitis, or sore mouth (Hosamani et al ,2009). Lesions of orf progress from erythema, vesicle formation, pustules and then scabs (Joseph et al ,2015 ). The disease are distributed globally over the word specially in sheep fields and had an zoonotic pattern, Since, it's also infected human beings (Zhang et al ,2012). Infection occurs via direct contact with the virus which is highly resistant and can survive in the environment for more than one year (Constable et al ,2017). The disease occurs most commonly in young lambs, but occasionally in older sheep, Grazing of coarse pastures or stubbles may predispose to infection with scabby mouth as oral abrasions increase the potential for the virus to gain entry (Kumar et al ,2015 ). In Basrah governorate, there was no real document clarify the disease and little information had been provided in sheep, therefore, the main aims of the current study were to study and explore the main clinical manifestations of the disease showed by diseased sheep, and confirmed the diagnosis of the causative virus using molecular method, PCR technique, Moreover to study the hematological changes in diseased animals, Evaluation of acute phase response of diseased animals via evaluation of haptoglobin and Fibrinogen.

\section{Animals and study design}

\section{Material And Methods}

The study was carried out on (132) local sheep breeds, aged 3-8 months and of both sexes. Animals were reared in Basrah Governorate, Basrah, Iraq. One hundred and twenty two (122) animals show the cardinal signs of contagious ecthyma and, Ten (10) clinically normal local sheep breeds was considered as controls 
.Complete clinical examinations had been carried out in all animals, Moreover, body temperature, respiratory and heart rate were also recorded.

Collection of samples and hematology

Ten milliliters of blood $(10 \mathrm{~mL})$ were drained from each animal by jugular vein puncture and from these (2.5) milliliter of blood mixed with EDTA used to determine Total erythrocyte count (TRBc), Hemoglobin concentration (Hb), packed cell volume (PCV), and Total leukocytes count (TLC), (Hematology analyzer, Genex, USA), Moreover differential leukocytes count were done using Giemsa stain blood smears method according to Weiss and Wardrop (2010), Furthermore erythrocytes sedimentation rate (ESR)were also estimated according to (Stevens et al , 2012) .

\section{Preparation of specimens and DNA extraction}

Scab materials were collected from papular lesions of upper and lower lips and from the muzzle of diseased animals. The collected scab materials were hashing to made as $10 \%$ scab suspension with phosphate buffered saline, Followed by centrifuged at $2000 \mathrm{rpm}$ for $10 \mathrm{~min}$. The supernatent were used for viral DNA extraction via Geneaid Virus DNA Extraction Kit following the manufactures instructions. The DNA was kept at $-20^{\circ} \mathrm{C}$ until use.

\section{Primers}

The primer sequences used for amplification of partial GIF / IL-2 gene were:

Forward primer : 5' gct cta gga aag atg gcg tg-3'

Reverse primer : 5' gta ctc ctg gct gaa gag cg 3' (Deane et al., 2000)

GIF/IL-2 gene is the virulence factor found only in Parapox viruses (GIF gene accession number AF192803 (Ramesh et al ,2008). The primers were synthesized commercially and supplied by the Bioneer Company, Republic of Korea.

Polymerase chain reaction

The extracted DNA was subjected to PCR technique. DNA amplification was performed using the AccuPower ${ }^{\circledR}$ PCR PreMix Kit following the manufacture's instructions. PCR cycling conditions include initial denaturation at $94^{\circ} \mathrm{C}$ for 5 minutes, followed by denaturation at $94^{\circ} \mathrm{C}$ for 30 seconds annealing at $57^{\circ} \mathrm{C}$ for 1 minute and extension at $72^{\circ} \mathrm{C}$ for 1 minute. The 35 cycles were followed by a final extension at $72^{\circ} \mathrm{C}$ for 10 minutes (Deane et al., 2000).

Gel electrophoresis

The amplified DNA product was electrophoresed on $2 \%$ agarose gel prepared in TBE buffer and the gel was visualized using an ultraviolet transilluminator and photos were taken.

Serological and biochemical analysis

Serum was obtained for evaluation of acute phase response, including estimation of Haptoglobin (Haptoglobin Elisa method) (Biotechnology co -china) and Fibrinogen (Blood mixed with trisodium citrate using plasma) (Biolabo / France), according to manufacture instructions.

Statistical analysis

Data were analyzed and the significant difference between diseased and control group were statistically indicated using (SPSS program) student t-test (Leech et al, 2007).

\section{Results}

Diseased sheep show different clinical manifestations, According to their severity, clinical signs were appearing different in animals, However, Disease animals show signs of anorexia, depression, dullness, Moreover, contagious ecthyma lesions are severe and restricted to the skin in the form of excretive, inclusive, diffusive painful papular and or pustular lesions appear at mouth commeasure, upper and lower part of the lips (Fig. 1) And on the muzzle, Moreover, Some infective lesions appeared also on the nose, Furthermore, lesion of upper eyelid were indicated in one animal, On the other hand, some animals show more advanced lesions in the form of thicker, brownish, rapidly accretive scabs with granulation (Fig.2), which when removed, leave an area of raw bleeding . Orf lesions had an offensive odor and in some severe infection fissure formation was observed on the lower lip. A significant increase $(p<0.05)$ was encountered in body temperature, respiratory and heart rate of diseased sheep affected with contagious ecthyma than in controls, Table 1. Diagnosis of contagious ecthyma in the current study was confirmed by PCR test (Figure3). Since positive samples by PCR were shown the suspected PCR amplicon size of $408 \mathrm{bp}$. Results of hematological examination of diseased sheep infected with contagious ecthyma and controls indicated leuckocytosis due to a significant $(\mathrm{p}<0.05)$ increase in the number of total leukocyte count and lymphocytosis due to the significant increase $(p<0.05)$ in the absolute number of lymphocytes, Moreover the rate of erythrocyte sedimentation of red blood cells indicated a significant increase $(\mathrm{p}<0.05)$ in diseased sheep than in controls, Table 2. Data concerning acute phase response 
revealed a significance increase $(\mathrm{p}<0.05)$ in both Haptoglobin values and Fibrinogen time in diseased sheep with contagious ecthyma and controls, Table 3.

\section{Discussion}

Contagious ecthyma is an important infectious viral skin disease affecting small ruminants specially sheep and goats, The disease might be neglected worldwide now a days because of low morbidity reflecting by the strong control measures applying globally, Nevertheless, in Basrah, Iraq there was no real document concerning the epidemiological aspect of this disease despite the increase frequency of orf disease outbreak, Moreover an important reason for investigating orf disease was its zoonotic potential although no human infections were reported in this study, it is not possible to completely ruleout the presence of zoonotic orf infections.

Diseased sheep show different clinical signs which were also mentioned by others (Hosamani et al ,2009 ., Nandi et al ,2011., Scott et al , 2014., Joseph et al ,2015 ), Since infection occurs by direct contact with the virus which is highly resistant and can survive in the environment for more than one year, In addition the disease occurs most commonly in young ages, However occasionally seen also in older sheep whom mostly grazing of rough pastures those had an cut stalks of cereal plants that may predispose to infection with scabby mouth as oral abrasions increase the potential for the virus to gain entry (Constable et al ,2017).

In general contagious ecthyma will commonly affects animal lips, However mouth and surrounding skin were also harmed, Furthermore the disease can also affect the face, feet and even the udder skin of lactating ewes, As the causative virus will causes superficial sores, which then will crusted and finally scabbing over and then falling down, Moreover, the underlying skin heals without scarring, where, this cycle takes approximately 4-5weeks or maybe less, Thereby lambs lose condition as they are reluctant to eat and it is too painful for ewes to feed suckling lambs, However, those with foot lesions will be lame, Furthermore, these sores may become infected by opportunistic bacteria, causing further infection (Kumar et al, 2015).

It had been documented that Orf lesions evolve through the stages of macule, papule, vesicle, pustule, scab formation, and resolution. Orf pustules will develop within a few days, However, when it will ruptured ulcers and a thick scab will formed which shed within 3-4 weeks, leaving no scar tissue, Although the immunity is solid but could only last for eight months, In addition, there was an antibody response to the virus, Moreover, a secondary bacterial infection, may occur sometimes following recovery from a primary infection (de la Concha-Bermejillo et al ,2003 ., Abbas and Mughal,2014).

The classical roles for diagnosis, which might depend on histopathological examinations and clinical manifestations were less accurate, Since the isolation of the virus is thought to be the golden standard method, but its need time (Haig, 2006), Nevertheless, with the development of molecular biology, as the PCR technique is widely used to amplify the describe genomic fragments from the specimens of diseased sheep and it has a strong tool in molecular diagnosis. The results of the current study were in same sporting data with (Torfason et al ,2002 ., Li et al ,2012., Martins et al , 2014 ., Gelaye et al ,2016), Since PCR technique was used for diagnosis of contagious ecthyma thereby samples were found positive by PCR showing the predicted PCR amplicon size of $408 \mathrm{bp}$.

Results of the current study indicated leukocytosis due to significant increase in lymphocytes number (Lymphocytosis) same results were also mentioned by (Weiss and Wardrop 2010), Since leukocytosis can be indicated as a reaction to different infectious, inflammatory, However in those conditions, This reaction could be mediated by several molecules, which are released in response to stimulatory events that include growth or survival factors such as granulocyte colony-stimulating factor, granulocyte-macrophage colony-stimulating factor, c-kit ligand, or adhesion molecules and various cytokines (Jain, 1993), Moreover because the demands on the leukocyte producing tissues in the bone marrow have increased to the point at which there is an insufficient number of mature cells for delivery into the circulation, as the infection subsides, the number of younger forms and the total white cell count decrease and ultimately return to normal, during the period of repair following an inflammatory reaction, the monocytes may increase in number, and subsequently the lymphocytes will become more numerous (Harvey, 2012), on the other hand, Certain types of infection specially viral types are characterized from the beginning by an increase in the number of small lymphocytes unaccompanied by increases in monocytes or granulocytes, and such lymphocytosis is usually of viral origin, However, moderate degrees of lymphocytosis are encountered in certain early acute and chronic infections,

(Reagan et al ,2008), Furthermore , (Thrall et al ,2012) added that some infectious diseases, caused by some viral infection were associated with the appearance of unusually large lymphocytes (atypical lymphocytes), Since These cells represent part of the complex defense mechanism against the virus, and they disappear from the blood when the attack of that virus were subsiding. Results were also indicated a significant increase in ESR values in diseased sheep than in controls which agreed with (Jain,1993), who refers to the correlation between the sedimentation of RBCs and severity of inflammation and severe infection marked by an increase in globulins where the increase settling of RBCs will take place faster when the inflammation being so acute and 
severe, although the rate of sedimentation were also will be high when three is anemia and in other conditions like arthritis.

The varied reactions of the host to infection, inflammation, and trauma are known as the acute-phase response and investing a wide range of pathological and physiological reflexes such as fever, Leucocytosis, alterations of hormone, and tissue damage ,However it might enhance the repair process (Ceciliani et al ,2012), The real mechanism for enhancing stimulation of hepatic production of acute phase proteins is through proinflammatory cytokines ,Since, the mean roles and functions of positive acute-phase proteins in optimization and trapping of microorganism and their products, or activating the complement system, and also in binding cellular remnants like nuclear fractions, Furthermore in neutralizing enzymes, However scavenging of free hemoglobin and radicals were also done, and finally, for alteration the immune response of the host, Moreover, acute-phase proteins can be used as diagnostic guide for many diseases (Gabay and Kushner, 1999). The results of the current study reveals a positive response of acute phase response represented by a significant increase in values of haptoglobin and fibrinogen which were agreed with others (Gentry ,1999., Ceciliani et al ,2012 ). The acute phase response is a known complex reaction, involving local and systemic effects. One of these effects corresponds to changes in the concentration of some plasma proteins, mainly synthesized in the liver, which are called acute phase proteins as the acute phase response will indicated by a specific protein hormones called cytokines which were acting as a corresponding agents between the local site of injury and the hepatocytes synthesizing the acute phase response, However most cytokines have multiple sources, targets, and also different functions, Furthermore it have been found in a large number of animal species including mammals, birds, fish, and others (Hiss et al 2004). The changes in the concentrations of acute phase proteins are largely due to changes in their production by hepatocytes and the maximum serum concentration of these proteins is typically reached within 24 to $48 \mathrm{~h}$ after the initiation, However, A decline coinciding with the recovery from the infection is seen,(Humbl et al ,2006).

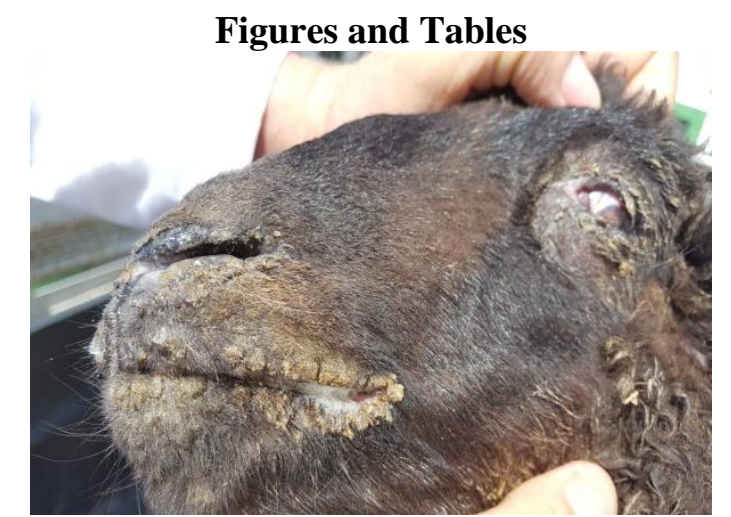

Fig. 1: Photograph of a sheep showing severe proliferative orf lesions on upper and lower lips

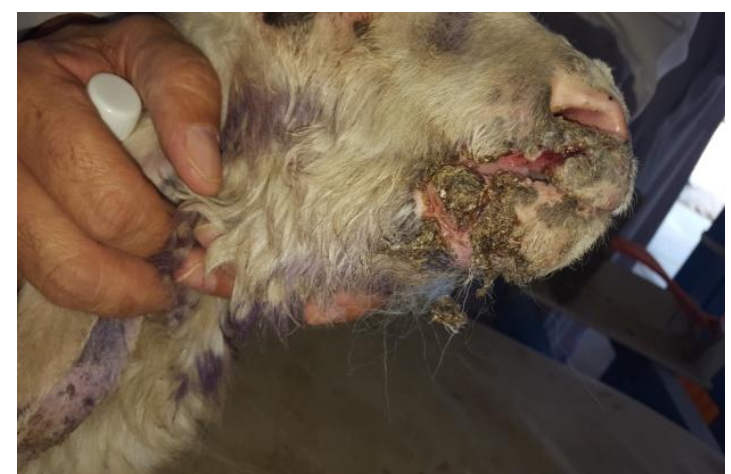

Fig 2: Photograph of a sheep showing proliferative orf lesions with thick, brown, scabs

Table 1: Body temperature, respiratory and heart rate of diseased sheep and controls

\begin{tabular}{|l|c|c|}
\hline \multicolumn{1}{|c|}{ Parameters } & $\begin{array}{c}\text { Controls } \\
\mathrm{n}=7\end{array}$ & $\begin{array}{c}\text { Diseased sheep } \\
\mathrm{n}=38\end{array}$ \\
\hline Body temperature $/ \mathrm{C}^{\circ}$ & $39.45 \pm 1.26$ & $41.4 \pm 1.4^{* *}$ \\
\hline Respiratory rate $/ \mathrm{mint}$ & $24.38 \pm 7.53$ & $78.4 \pm 12.3^{* *}$ \\
\hline Heart rate/mint & $87.3 \pm 8.4$ & $134.7 \pm 17.58^{* *}$ \\
\hline
\end{tabular}

Values are mean \pm standard error of mean. ** $(P<0.05)$. 


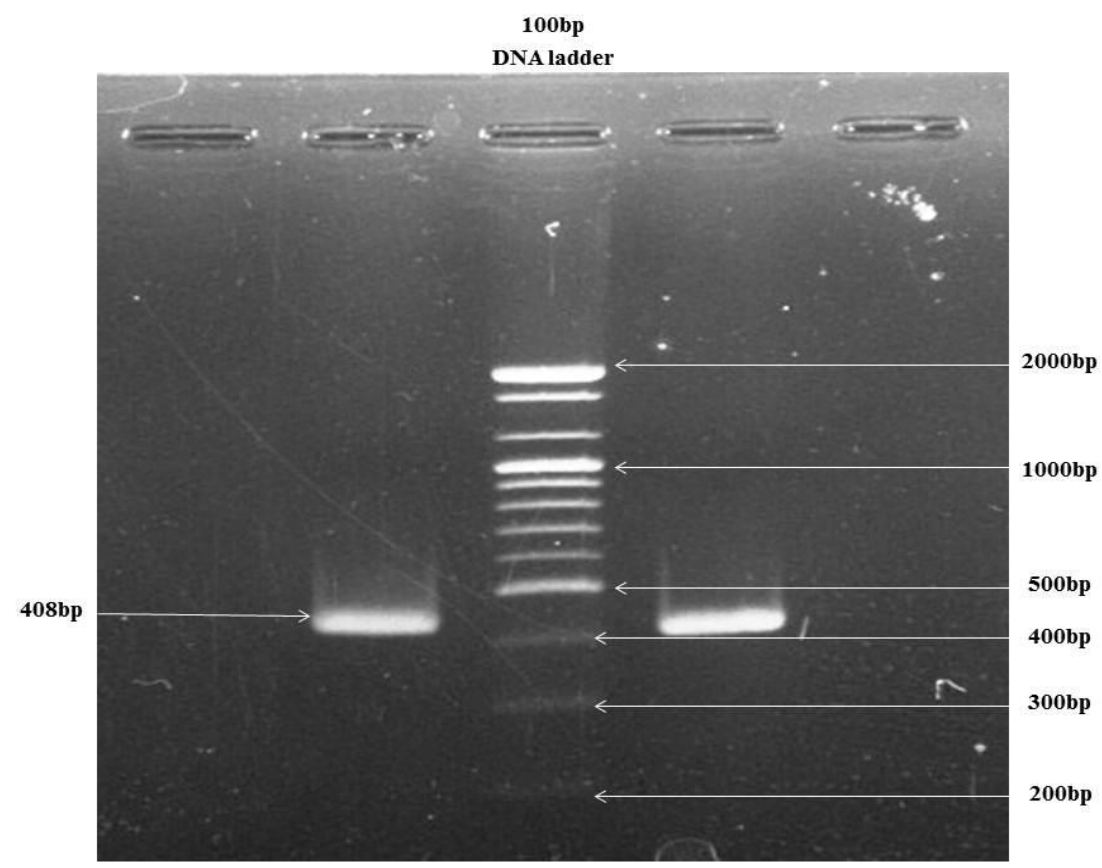

Fig 3: Agarose gel electrophoresis showing PCR amplicons. Positive result (408bp band) appears clearly on the gel

Table 2: Hematological parameters of diseased sheep with contagious ecthyma and controls

\begin{tabular}{|l|c|c|}
\hline Parameters & $\begin{array}{c}\text { Controls } \\
\mathrm{n}=7\end{array}$ & $\begin{array}{c}\text { Diseased sheep } \\
\mathrm{n}=38\end{array}$ \\
\hline $\mathrm{RBCs} 10^{6}$ & $7.83 \pm 1.23$ & $7.57 \pm 1.21$ \\
\hline $\mathrm{Hb}$ g/dl & $12.91 \pm 2.66$ & $12.72 \pm 1.42$ \\
\hline PCV \% & $33.2 \pm 3.45$ & $35.46 \pm 3.62$ \\
\hline TLC $\times 103$ & $9.76 \pm 3.25$ & $14.65 \pm 2.78^{* *}$ \\
\hline Lymphocytes (Absolute) & $4352 \pm 321.53$ & $8810 \pm 456^{* *}$ \\
\hline Nutrophiles (Absolute) & $4284 \pm 162.21$ & $4844 \pm 345$ \\
\hline onocytes (Absolute) & $542 \pm 62$ & $320 \pm 74$ \\
\hline Eosinophiles (Absolute) & $452 \pm 134$ & $79 \pm 65$ \\
\hline Basophiles (Absolute) & $83 \pm 65$ & $16.72 \pm 4.52 * *$ \\
\hline ESR mm/24hr & $7.86 \pm 5.62$ & \\
\hline
\end{tabular}

Values are mean \pm standard error of mean. $* *(P<0.05)$.

Table 3:Acute phase response of sheep with contagious ecthyma and controls

\begin{tabular}{|l|c|c|}
\hline Parameters & $\begin{array}{c}\text { Controls } \\
\mathrm{n}=7\end{array}$ & $\begin{array}{c}\text { Infected sheep } \\
\mathrm{n}=38\end{array}$ \\
\hline Haptoglobin g/dl & $0.023 \pm 0.012$ & $0.045 . \pm 0.006^{* *}$ \\
\hline Fibringen time / sec & $23.88 \pm 7.41$. & $31.45 \pm 6.73 * *$ \\
\hline
\end{tabular}

Values are mean \pm standard error of mean. $* *(P<0.05)$.

\section{Conclusions}

It has been concluded that contagious ecthyma were infect local sheep breeds of Basrah Governorate lead to different clinical manifestations which might cause weakness and retarded growth of infected animals due to high morbidity and in severe cases when secondary infection might occur the disease may terminate with the death of diseased animals, Therefore Annual vaccination programs must apply to all suspected animals at endemic areas.

\section{References}

[1] A Ramesh , V.S. Vadivoo, B.S. Suresh, K.Saravanabava, Confirmatory diagnosis of contagious ecthyma by amplification of the GIF / IL-2 gene by PCR. Tamilnadu J. Vet . Ani. Sci. 4 ,(6) ,2008, 208-210.

[2] A Stevens, SL James, and S Ia, Veterinary Hematology. Elsevier Inc. 2012.

[3] B.G Turk, B. Senturk, T. Dereli, B.Yaman, A rare human-to-human transmission of orf. Int. J. Dermatol. 53,(1) ,2014, e63-5.

[4] C de Wet, J . Murie, Lamb pays lip service: two cases of ecthyma contagiosum (orf ). Scott. Med. J, 56,(1), $2011,59$.

[5] C.Gabay, I.Kushner, Acute-phase proteins and other systemic responses to inflammation. New England J. Med.340, 1999, 448454. 
[6] D Deane, C.J. McImes, A. Percival, A. Wood, J. Thomson, A. Lear, J. Gilray, S. Fleming, A . Mercer, D. Haig ,Orf virus encodes a novel secreted protein inhibitor of granulocyte-Macrophage colony-stimulating factor and interleukin-2. Virol. $74,3,2000,1313$ -1320 .

[7] D.J Weiss and K.J. Wardrop, Schalm's Veterinary Hematology, $6^{\text {th }}$ Ed, Ames, Wiley-182 ,Blackwell. 2010.

[8] D.M Haig, Orf virus infection and host immunity. Curr. Opin. Infect. Dise. 19,(2),2006, 127-131.

[9] de la Concha-Bermejillo, J. Guo, Z. Zhang, D.Waldron ,Severe persistent orf in young goats. Vet. Diag. Invest. 15,(5),2003, 42331.

[10] E Gelaye and J.E Achenbach, E Achenbach, S Jenberie, G Ayelet, A Belay, M Yami, A Loitsch, R Grabherr, A Diallo, and CE Lamien, Molecular characterization of orf virus from sheep and goats in Ethiopia, 2008-2013. Virol J. 29 (13) $2016,34$.

[11] E.G Torfason And S.Gunadottir, Polymerase chain reaction for laboratory diagnosis of orf virus infections. J .Clin .Virol. 24, 2002, 79-84.

[12] F Ceciliani, J.J Ceron, P.D Eckersall, H.Sauerwein ,Acute phase proteins in ruminants. J. Proteo. 75, $20124207-4231$.

[13] G Abbas, and M.N. Mughal,Case report on orf in sheep in Faisalabad , Pakistan. Int. J. Mol. Vet. Res. 4,(1), 2014 1-2.

[14] G Delhon, E.R Tulman, C.L Afonso, Z. Lu1, A. de la Concha-Bermejillo,H. D. Lehmkuhl, M. E. Piccone, G. F. Kutish, D. L.

Rock, Genomes of the parapoxviruses ORF virus and bovine papular stomatitis virus. J Virol. 78, 2004, $168-77$.

[15] J Harvey, Veterinary hematology, Saunders. 2012.

[16] K Midilli , A. Erkiliç, M. Kuşkucu, H. Analay, S. Erkiliç, N. Benzonana, M.S. Yildirim, K. Mülayim, H. Acar, O. Ergonul, Nosocomial outbreak of disseminated orf infection in a burn unit, Gaziantep, Turkey, October to December 2012. Euro. Surveill. $18,(11), 2013,1-5$.

[17] K Zhang, Y. Liu, H. Kong, Y. Shang, X. Liu, Human infection with ORF virus from goats in China. Vector Borne Zoonotic Dis. 14,2014, 365-7.

[18] K.A Hussain, Y.A. Yousuf, T.S. Qubit, Contagious ecthyma in sheep in Mosul area. Iraqi J. Vet. Sci. 5, $1992,77-84$.

[19] KW Chan, C.H Yang, J.W Lin, HC Wang, FY Li, ST Kuo, M.L Wong, WL Hsu, Phylogenetic analysis of parapoxviruses and the C- terminal heterogeneity of viral ATPase proteins. Gene. 432, 2009, 44-53.

[20] M Giangaspero, B. Bonfini, R. Orusa, G. Savini, T. Osawa, R. Harasawa , Epidemiological survey for Toxoplasma gondii, Chlamydia psittaci var. ovis, Mycobacterium paratuberculosis, Coxiella burnetii, Brucella spp., leptospirosis and Orf virus among sheep from northern districts of Japan. J. Vet. Med. Sci. 75,(5), 6 ,2013,79-684.

[21] M Hosamani, A. Scagliarini, V. Bhanuprakash, C.J. McInnes, R.K. Singh, Orf: an update on current research and future perspectives. Expert. Rev. Anti. Infect. Ther. 7, 2009, 879-93.

[22] M Martins, J.F. Cargnelutti, R. Weiblen, E.F. Flores, Pathogenesis in lambs and sequence analysis of putative virulence genes of Brazilian orf virus isolates. Vet. Microbiol. 174,(1-2),2014, 69-77.

[23] M.A Thrall, G. Weiser, R. Allison, T.W. Campbell, Veterinary Hematology and Clinical Chemistry, $2^{\text {nd }}$ Ed. Wiley-Blackwell. 2012.

[24] M.F Humblet, H. Guyot, B. Boudry, F. Mbayahi, C. Hanzen, F. Rollin, J.M. Godeau, Relationship between haptoglobin, serum amyloid A, and clinical status in a survey of dairy herds during a 6-month period. Vet. Clin. Pathol. 35, 2006,188-193.

[25] M.S Gurel, I. Ozardali, M. Bitiren, I. San, H . Zeren ,Giant orf on the nose. Eur. J. Dermatol. 12, 2002, $183-185$.

[26] N.C Jain, Essentials of Veterinary Hematology. $1^{\text {st }}$ ed. Lea and Febiger. Philade-lephia. 1993, 121-123.

[27] N.J MacLachlan and E.J.Dubovi, Poxviridae. In: Fenner's Veterinary Virology. $4^{\text {th }}$ ed. London: Academic. 2011, 151-65.

[28] N.L Leech, K.C Barrett, G.A. Morgan, SPSS for intermediate statistics: use and interpretation $.1^{\text {st }}$ Ed. Lawrence Erlbaum Asso.USA. 2007, 20-51.

[29] P.A Gentry, Acute phase proteins. In: Loeb WF, Quimby FW (eds.): Clinical Chemistry of Laboratory Animals. Taylor \& Francis, Philadelphia, 1999, 336-398.

[30] P.R Scott, Overview of contagious ecthyma. In: Kahn CM, Line S, Aiello SE, editors. The Merck veterinary manual. $10^{\text {th }}$ ed. Whitehouse Station, NJ: Merck and Co. 2105.

[31] PD Constable, KW Hinchcliff, S.H Done, W. Grunberg, Veterinary Medicine. A textbook of the diseases of cattle, sheep, goats and horses. $11^{\text {th }}$ ed, WB Saunders Co. 2017, 1593-1596.

[32] R Kumar, R.N. Trivedi, P. Bhatt, S.U.H. Khan, S.K. Khurana, R. Tiwari , K. Karthik, Y.S. Malik, K. Dhama, R.Chandra, Contagious Pustular Dermatitis (Orf Disease) - Epidemiology, Diagnosis, Control and Public Health Concerns. Adv. Ani. Vet. Sci. $3,(12), 2015,649$.

[33] R.H Joseph, F.A. Haddad, A.L. Matthews, A. Maroufi, B. Monroe, M .Reynolds, Erythema multiforme after orf virus infection: a report of two cases and literature review. Epidemiol. Infect. 143,(2),2015, 385-90.

[34] S Hiss, M.Mielenz, R.M. Bruckmaier, H.Sauerwein, Haptoglobin Concentrations in Blood and Milk After Endotoxin Challenge and Quantification of Mammary Hp mRNA Expression.J. Dairy Sci. 87, 2004, 3778-3784.

[35] S Nandi, U.K. De, S.Chowdhury, Current status of contagious ecthyma or orf disease in goat and sheep GÇöA global perspective. Small Rumin. Res. 96, 2011, 73-82.

[36] S.J Key, J. Catania , S.F Mustafa , R. Logan , M. Kalavala , S.C. Hodder , D.W. Patton, Unusual presentation of human giant orf (Ecthyma Contagiosum). J.Craniofac. Surg. 18,(5), 2007, 1076- 1078.

[37] W Li, Z. Ning, W. Hao, D. Song, F. Gao, K. Zhao, X. Liao, M. Li, D.L.Rock, S.Luo, Isolation and phylogenetic analysis of orf virus from the sheep herd outbreak in northeast China. BMC. Vet. Res. 8, 2012, 229.

[38] W.J.Reagan, R. Armando, I. Rovira, Veterinary Hematology, Atlas of Common Domestic and non domestic species .WileyBlackWell. 2008.

Kamal M Al Saad. "Clinical and Diagnostic Studies of Contagious Ecthyma (ORF) In Sheep ." IOSR Journal of Agriculture and Veterinary Science (IOSR-JAVS) 10.7 (2017): 64-69. 